\title{
FINDING SENSORY PROFILERS AMONGST RED WINE COMPOSITION: A NOVEL NATIONWIDE APPROACH
}

\section{EM BUSCA DE MARCADORES SENSORIAIS POR ENTRE A COMPOSIÇÃO DO VINHO TINTO: UM ESTUDO NACIONAL INOVADOR}

\author{
Anibal Jose-Coutinho ${ }^{1 *}$, Patricia Avila², Jorge M. Ricardo-da-Silva ${ }^{1}$ \\ ${ }^{1}$ Universidade de Lisboa, Instituto Superior de Agronomia, Linking Landscape Environment Agriculture and Food (LEAF), Laboratório Ferreira \\ Lapa (Sector de Enologia), Tapada da Ajuda, 1349-017 Lisbon, Portugal. \\ ${ }^{2}$ Instituto Universitário de Lisboa (ISCTE-IUL), Av. das Forças Armadas, 1649-026 Lisbon, Portugal.
}

*corresponding author: Tel: +917223808, e-mail: ajosecoutinho@gmail.com

(Received 29.09.2015. Accepted 05.11.2015)

\section{SUMMARY}

The objective of this work was to verify the signaling/profiling potential of wine compounds and the physicochemical and bioclimatic winerelated measurements on a nationwide sensory scale of red wine typicality. Color tonality evolved from violet-purple in cooler northern regions to ruby-garnet in hotter southern regions. Acidity and astringency were enhanced from south to north. Conversely, alcohol and viscosity progressed southward. Bitterness was primarily affected by inland-coastal influence. The regional differentiation of astringency and bitterness introduced an orthogonal reading ( $\mathrm{N}$ north- $\mathrm{S}$ south vs. E inland-W coastal, respectively), rather than a linear one, these findings adding novelty to sensory research. Additionally, several Portuguese-related studies were reviewed, and their findings were correlated with six sensory measures. Bioclimatic indexes, $\mathrm{pH}$ and the total phenol index were considered the strongest profilers in a nationwide assessment on red wine typicality. The ratio of the oligomeric/polymeric composition of tannins, as well as total anthocyanins, was also to be considered to be a valid sensory profiler. Several nationwide tendencies and correlations between sensory evaluations and wine chemistry may represent interesting findings and challenge unexplored ways for new research.

\section{RESUMO}

O objetivo deste estudo foi a verificação da existência de potenciais indicadores/marcadores da tipicidade sensorial dos vinhos tintos à escala nacional, entre os compostos que constituem o vinho, analisando, também, alguns índices físico-químicos e bioclimáticos, com ele relacionados. A tonalidade da cor evoluiu de violeta-púrpura nas regiões mais frias e nortenhas para rubi-granada nas regiões quentes do sul. A acidez e a adstringência subiram de sul para norte, contrastando com as perceções derivadas do álcool e viscosidade que aumentaram para sul. O amargor sofreu a influência maioritária da direção atlântico-continente, aumentando no sentido costeiro. A diferenciação regional entre a adstringência e o amargor introduziu uma leitura ortogonal ( $\mathrm{N}$ norte - S sul vs. E continente - W atlântico), constituindo esta relação cruzada um inovador contributo para a investigação sensorial. Ainda no âmbito deste trabalho, vários estudos acerca de vinhos portugueses foram compilados e os seus dados relativos à composição dos vinhos analisados, bem como alguns índices físico-químicos e bioclimáticos, foram correlacionados com seis medidas sensoriais. Os índices bioclimáticos, o $\mathrm{pH}$ e o índice de fenóis totais foram considerados os mais fortes marcadores para uma caracterização sensorial da tipicidade dos vinhos tintos à escala nacional. O rácio da composição de taninos oligoméricos/poliméricos, assim como o teor de antocianinas totais, também poderão ser marcadores sensoriais válidos a considerar. Várias tendências à escala nacional, bem como correlações entre medidas sensoriais e a composição química do vinho tinto poderão representar resultados interessantes e abrir novas vias de investigação da ciência e técnica vitivinícola.

Key words: typicality signaling, color, taste, red wine astringency, bitterness.

Palavras-chave: marcadores de tipicidade, cor, gosto, adstringência do vinho tinto, amargor.

\section{INTRODUCTION}

A terroir product is issued from a geographical region with a specific climate and is created based on the knowledge of the qualities of that place (Spielmann, 2012). A wine is typical if some of its own characteristics can be identified and make it recognizable as belonging to a regional or cultural 69

This is an Open Access article distributed under the terms of the Creative Commons Attribution License (http://creativecommons.org/licenses/by/4.0), which permits unrestricted use, distribution, and reproduction in any medium, provided the original work is properly cited. 
type and distinctive from others (Maitre et al., 2010). It is the shared perception of how generations of people from a given place expect the wine to taste (Vaudour and Shaw, 2005). Is it possible to obtain an agreement on sensory typicality inside a vast Protected Geographical Indication (PGI) or even in smaller Protected Designation of Origin (PDO) legally and geographically located inside a PGI? When there is consensus, which methodology can be used to describe it? These key questions remain scarcely answered.

Multivariate statistical approaches have prompted the development of methods for the analysis of hedonic and analytical sensory data, and their interactions (Tuorila and Monteleone, 2009). Concerns on the scarcity of samples assessed have always undermined the results on typicality. Do 6, 10, or 14 wine samples statistically represent and explain typicality over a vast wine region? Developing a method that would bypass the sampling problem of wines that would be representative of a given PGI is, to our knowledge, a useful and original idea.

Phenolic signaling within the plants is not well documented (Cheynier et al., 2013); however, the determination of phenolic compounds as key profilers for wine typicality has been suggested by several research teams (Fernández-Pachón et al., 2004; Vidal et al., 2004a; Lesschaeve and Noble, 2005; Suarez et al., 2007; Cosme et al., 2009; Vilanova et al., 2010; McRae and Kennedy, 2011; Cabrita et al., 2012; Sun et al., 2013; Quijada-Morín et al., 2014). Findings on bioclimatic zoning in Mainland Portugal were published (Magalhães et al., 1995; Fraga et al., 2013).

Phenolic compounds constitute one of the most important quality parameters of wines, because they contribute to wine organoleptic characteristics such as color, astringency, bitterness and aroma. The phenolic composition of wines is conditioned by the grape variety and by other factors that affect the berry development, such as soil, geographical location and weather conditions (Monagas et al., 2005). Phenolic compounds in red wines include both non-colored compounds (i.e., flavan-3-ols, flavonols, phenolic acids, stilbenes), potentially colored anthocyanins and anthocyanin derivatives (Boulton 2001; Alcalde-Eon et al., 2006; Dopico-García et al., 2008; Marquez et al., 2013). Flavanol oligomers and polymers are also called condensed tannins or proanthocyanidins. Flavonoids are prone to interact between them and with other wine constituents such as proteins or polysaccharides (Charlton et al., 2002). Astringency is a fundamental sensation for a wine, particularly red wines that are rich in polyphenols, mainly from grape seeds and skins. It is acknowledged that high-quality red wines are balanced wines that have neither too much astringency, which would lead to a hard wine, nor too little, which would lead to an uninteresting and flat wine (Vidal et al., 2004b).

Bioclimatic indexes are useful metrics for assessing climatic influences on viticulture and thus can be used in viticulture zoning applications (Tonietto et al., 2014). By combining bioclimatic aspects of heat accumulation, dryness, and ripening conditions, it is possible to determine optimum viticulture suitability and directly compare between regions (Fraga et al., 2013).

The aim of this work was to verify the signaling/profiling potential of phenolic compounds, physicochemical and bioclimatic measurements on a nationwide sensory scale of red wine typicality. The aromatic composition of wine was not included in the scope of this research.

\section{MATERIAL AND METHODS}

The study involved two different stages:

\section{Determining inner key profilers, from a novel nationwide sensory study}

Based on nationwide sensory research (Jose-Coutinho et al., 2013, 2015), 20 Portuguese wine experts have completed 12 individual sensory questionnaires using their vast cognitive long-term memory regarding each of the sensory typicality of each of the 12 Portuguese PGI red wine regions (excluding the islands). No wine samples were assessed and no training phase was required. Instead the professional wine experts were asked to fill individually the questionnaires according to their prototypical long-term memory of each PGI red wine sensory profile, this method to be considered feasible and challenging to characterize macro-zoning or nationwide spaces. A restrictive approach to Parr (Parr et al., 2002) has been made to select expert respondents. The questionnaire was designed according to the classical three-tier sensory method of assessment: visual, aromatic and gustatory/tactile attributes (Noble et al., 1987; Fischer et al., 1999; Gawel et al., 2000; Gawel et al., 2001; Hernández et al., 2009). Color Tonality results were standardized to match the overall 11-integer-points scale, as a study by Hernández et al. (2009) justified the use of a 4-integer-points scale with 1 VioletPurple, 2 Purple-Ruby, 3 Ruby-Garnet and 4 GarnetBrick. After reducing the initial sensory measures with principal components analysis, a new comparison of the 12 regions was made and a cluster analysis was applied. Experts' typicality construct towards PGI for red wines in mainland Portugal led to 
a sensory aggregation around four clusters (Figure 1). This new insight into traditional methods of characterizing large territorial areas was confirmed as the results showed the ability to cluster 12 PGIs into four macro-zones with statistically significant differences. Sensory profiles were suggested, the PGI MINHO found to be the most typical of all of the
PGIs with several extreme ratings for color, aroma and taste. The SOUTHERN cluster of the four Mediterranean PGIs presented several extreme, therefore typical, sensory assessments, which were opposite to the profile of the single-clustered PGI Minho.

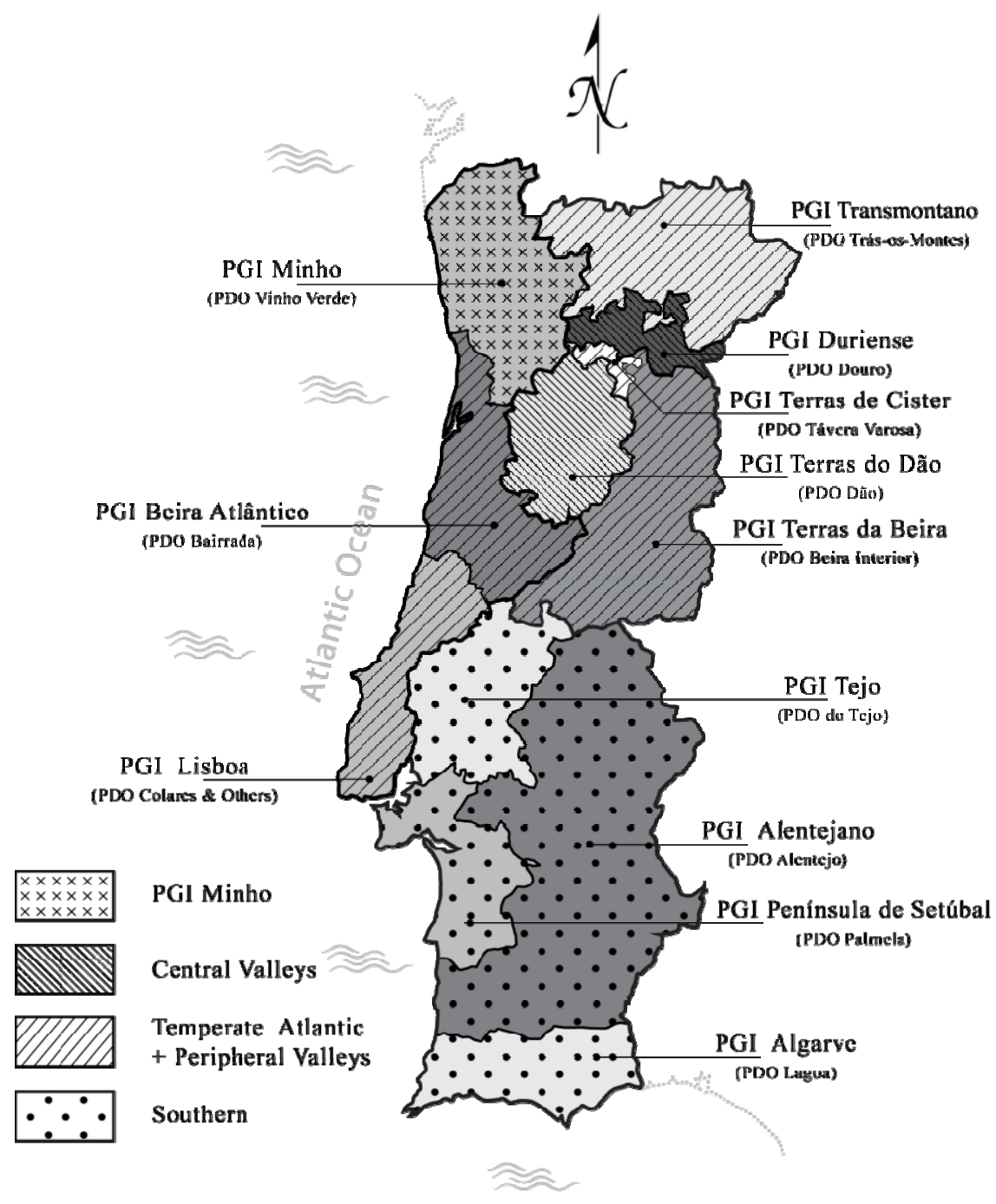

Figure 1. Protected Geographical Indications for wine production over mainland Portugal. Overlapping patterns show four sensory-typical clustered zonings.

Indicações Geográficas Protegidas para produção de vinho em Portugal Continental. Sobreposição de padrões gráficos para cada um dos quatro macro-zonamentos de tipicidade sensorial.

Differences amongst sensory ratings between wine regions were expressed using analysis of variance. Measure redundancy was assessed by inspection of the rotated factor loadings (after Varimax rotation) computed by principal component analysis (PCA) using the means of 14 rated tastant attributes as input 
(Table I). Two visual attributes - COLOR intensity and COLOR tonality - were retrieved from the raw data and computed along with four PCA latent variables - TASTE_dryastringent (PC1), TASTE_sweetviscous (PC2), TASTE_bittersalty
(PC3) and TASTE_fullpersistent (PC4). Considerations over the final six non odorant, phenolic-prone, sensory variables were made and segmented pair-wise scatterplots between heavily correlated variables were mapped.

Table I

Loadings of 14 tastant and mouthfeel descriptors in the first four principal components named: TASTE_dryastringent (PC1), TASTE_sweetviscous (PC2), TASTE_bittersalty (PC3) and TASTE_fullpersistent (PC4)

Scores fatoriais de 14 descritores sensoriais do gosto e do tacto, agrupados por 4 componentes principais designadas: GOSTO_secoadstringente (PC1), GOSTO_doceuntuoso (PC2), GOSTO_amargosalgado (PC3) e GOSTO_cheiopersistente (PC4)

\begin{tabular}{|c|c|c|c|c|}
\hline \multirow{2}{*}{ TASTE } & \multicolumn{4}{|c|}{ Principal Component (PC) } \\
\hline & 1 & 2 & 3 & 4 \\
\hline Grain (Mouthfeel) & $\underline{0.879}$ & -0.073 & 0.071 & 0.122 \\
\hline Rough (Mouthfeel) & $\underline{0.862}$ & -0.216 & 0.154 & 0.075 \\
\hline Astringent (Global) & $\underline{0.812}$ & -0.341 & 0.186 & 0.165 \\
\hline Dry (Mouthfeel) & $\underline{0.787}$ & -0.045 & 0.247 & -0.186 \\
\hline Sweet & -0.071 & $\underline{0.886}$ & 0.071 & -0.092 \\
\hline Alcohol & -0.299 & $\underline{0.799}$ & -0.113 & 0.168 \\
\hline Smooth (Mouthfeel) & -0.163 & $\underline{0.787}$ & -0.045 & 0.206 \\
\hline Oily (Mouthcoat) & 0.044 & $\underline{0.622}$ & -0.166 & 0.583 \\
\hline Acid (Sour) & 0.492 & $\underline{-0.621}$ & 0.363 & 0.187 \\
\hline Salty & 0.084 & 0.025 & $\underline{0.864}$ & 0.009 \\
\hline Bitter & 0.393 & -0.011 & $\underline{0.715}$ & 0.053 \\
\hline Bubbly & 0.167 & -0.395 & $\underline{0.572}$ & -0.209 \\
\hline Length & 0.188 & -0.107 & 0.077 & $\underline{0.862}$ \\
\hline Full body & -0.078 & 0.466 & -0.1 & $\underline{0.714}$ \\
\hline $\begin{array}{l}\text { Variance Explained } \\
\text { (cumulative) }\end{array}$ & $24.2(24.2)$ & $24.1(48.3)$ & $13.6(61.9)$ & $13.1(75.0)$ \\
\hline
\end{tabular}

\section{Determining outer key profilers from reviewed research on Portuguese wine chemistry and bioclimate.}

Differences in 11 measures between 12 PGI wine regions were retrieved on the basis of reviewed studies on Portuguese wine chemistry and climate (Table II). No attempt was made to gather a comprehensive review of the field, but rather, the goal was to highlight significant studies focused on Portuguese wine phenolic composition and bioclimatic characterization. It is important to note that the majority of these studies aimed to introduce new knowledge in specific and detailed lines of investigation, rather than to contribute to understanding key profiler measures for a characterization of nationwide typicality. Therefore, it is no surprise that the referenced research in Table II lacked a representative number of sampled wines to achieve statistical significance for a much broader reading. Simplification of those measurements using simple means was applied. At this point, a note of awareness for the lack of statistical significance of such few published studies must be added. In fact, all explanatory results should be reviewed on the basis of nationwide tendencies that must be confirmed a posteriori. 


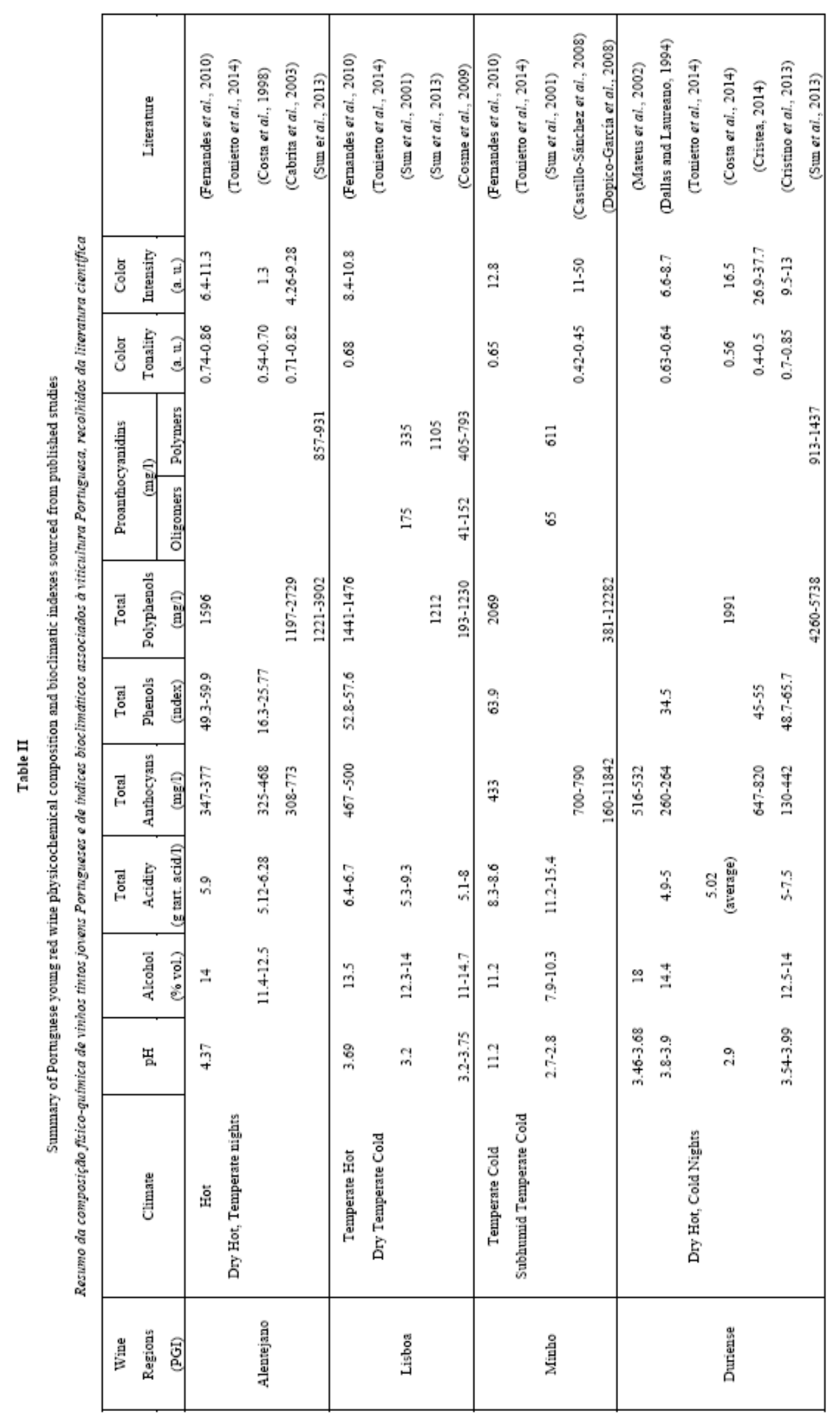




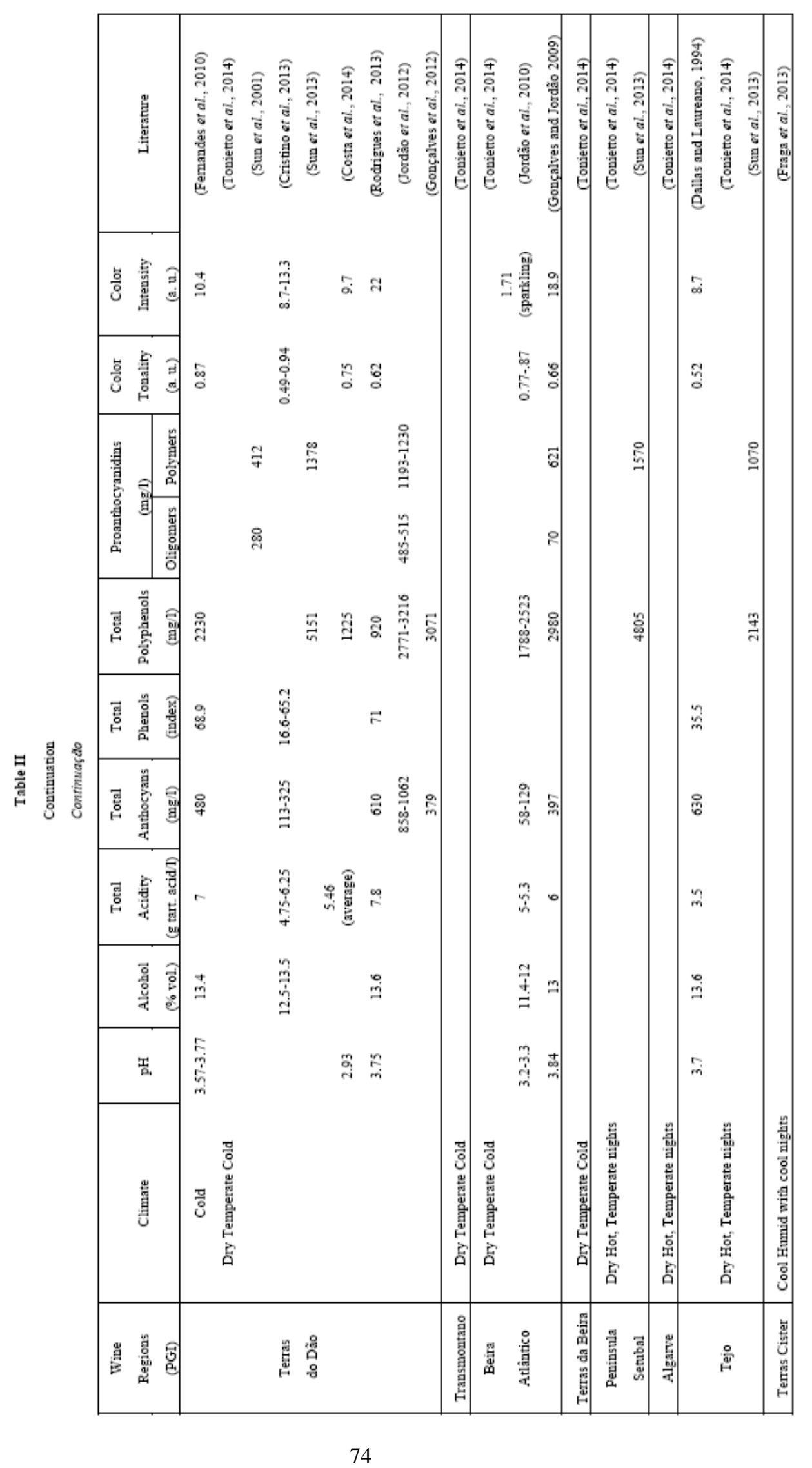


The six sensory variables from the nationwide sensory study and prospective signaling measures from the reviewed studies on Portuguese wine chemistry and climate were compared by correlating all pair-wise Euclidean distances and segmented pairwise scatterplots were made between heavily correlated variables. In both methodological steps IBM SPSS Statistics 22 (USA) was used for all statistical operations.

In both methodological steps, reported statistical methods involved also a Pearson correlation analysis, where the correlation coefficient represents the degree of linear association between two variables: positive values denote direct linear correlation, negative values denote inverse linear correlation, and a value of 0 shows no linear correlation; the closer the value is to 1 or -1 , the stronger the linear correlation is.

\section{RESULTS AND DISCUSSION}

\section{Inner key profilers from reported nationwide sensory research}

The 14 initial taste descriptors, based on the work of Peynaud and Blouin (1996), Gawel (1998) and Gawel et al. (2000, 2001), were statistically grouped into four Principal Components (PCs; Table I). PCs were named in accordance to sensory perceptions which are commonly cited in the scientific literature: TASTE_dryastringent (PC1), TASTE_sweetviscous (PC2), TASTE_bittersalty (PC3) and TASTE_fullpersistent (PC4).

All PCs are somehow related to the phenolic content in wine: PC1 included a full loading of astringency, showing the hard, dry-puckering side of astringent sensations, while PC2 included the soft, sweet and oily textures that may relate to phenolic interaction, mean degree of polymerization or cross-impact with alcohol or other compounds (Vidal et al., 2004b; McRae and Kennedy, 2011; Sun et al., 2011; Scollary et al., 2012). Red wine contains many astringent substances of different activities. Phenolic derivatives present in wine may taste either astringent, bitter or both (Valentova et al., 2002). Despite the close relationship between bitterness and astringent (Lesschaeve and Noble, 2005), our group of experts placed major factor loadings for each sensation in different principal components that strongly supported the perceived differentiation, as demonstrated in PC3, where bitterness stood alone with salty and fizzy sensations. PC4 encompasses fullness sensations and the notion of wine persistence. Certainly linked to phenolic content, the late variables have shown best in hedonic/sensory-prone studies (Vidal et al., 2004b; Cadot et al., 2010; McRae and Kennedy, 2011; Harrar and Spence, 2013) rather than in analytical ones.

Two initial color measures (García-Puente et al., 2006; Birse, 2007; Esparza et al., 2009; Hernández et al., 2009), which were related to colored phenolics (Boulton 2001; Mateus et al., 2002; Vivar-Quintana et al., 2002; Vidal et al., 2004a), completed the array of six phenolic-prone variables that were standardized, for full comparison, and were mutually correlated. The correlation analysis clearly indicated five significant paired variables (Table III), all of which were strongly related to wine phenolic content. Color tonality (also reported as color hue) presented several significant correlations to stand out as a strong profiler on typicality. The significant negative correlation between the two color measurements showed a geographical typicality between violetbluish toned wines and the highest Color intensities (Figure 2a). The knowledge of the color provided by each kind pigment, along with their relative amounts and the correspondence with their concentrations in wine, is necessary for the assessment of the contribution of each pigment family to the final color of the wine (Alcalde-Eon et al., 2006). Results clearly isolate PGI Minho as the most pigment-rich and as having typical violet-purple tonality. Cultivar influence may play a role in PGI Minho as local Vinhão teinturier-grapes were clearly differentiated by their high content in anthocyanins (97\%) with levels of phenolic compounds up to 16 times higher than the rest (Dopico-García et al., 2008). Climatic observations showed unison confirmation of south to north cooler conditions as well as inland (east) to coastal (west) wetter ones (Magalhães et al., 1995; Fraga et al., 2012; Fraga et al., 2013). Strong differentiation between the four southern regions (PGI Algarve, PGI Alentejano, PGI Península de Setúbal and PGI Tejo) and the farthest northwestern PGI Minho was achieved, as colored monomeric anthocyanins and/or bluish-like related polymeric adducts or copigments could suggest an extension of mouth-drying and mouth-roughness perceptions by the expert panel. With the increase in the copigments concentrations, González-Manzano et al. (2008) reported a certain decrease in the hue values, indicating a displacement towards more bluish hues. A possible explanation from mere colored phenolic concentration was not supportive, as the correlation Color Intensity vs. TASTE_dryastringent (PC1) was only weakly positive. The correlation between Color Tonality and TASTE_sweetviscous (PC2) also confirmed alcohol and $\mathrm{pH}$ enhancement towards the 
southern regions which relates to higher grape maturities. An increase in the hue value was to be expected, as maturation relates to a shift from purple red, via brick red, to brown tones of the wine color (Birse, 2007). Similarly, a research team showed a progressive rise in hue for all selected Portuguese wines, pointing out a transformation of violet-red to orange-red hue (Castillo-Sánchez et al., 2008), the different evolution of anthocyanin content, especially that of catechins and procyanidins, being the probable cause of changes in color stability. Similar sensory color evolution was reported in this study. Are those late findings applicable to cool climate vs. hot climate zoning? A high flavonol level has been reported in strongly sun-exposed grapes and in their corresponding wines, which has been associated with a greater extension of the flavonol-anthocyanin copigmentation phenomena, and therefore, with a greater stabilization of the red wine color (Monagas et al., 2005). Acknowledging the possibility of differences in regional anthocyanin composition and bonding, studies by Brouillard (1988) and Asenstorfer et al. (2006) stated that $\mathrm{pH}$ influenced the findings. In terms of color expression, isolated anthocyanins range from red with a purple tint at $\mathrm{pH} 1$ to purple at $\mathrm{pH} 4$ to blue at $\mathrm{pH} 7$, but ethyl-linked anthocyaninflavanol compounds, when predominant, show greater color stability and leading orange tonalities. Another recent review confirms that late compounds are responsible for a gradual change of the red-purple color towards orange hues, because these adducts have a more reddish-orange color than their anthocyanin counterparts (Marquez et al., 2013). The results of the present study showed that it was possible to differentiate PGI red wines by their Color Tonality (Figure 2a, 2b, 2c and 2d) but analytical support has yet to be confirmed, despite some cited aligned literature.

Table III

Pearson correlation matrix of six sensory variables.

Matriz com correlações de Pearson relativas às seis variáveis sensoriais.

\begin{tabular}{cccccccc}
\hline \hline & & color_ton & PC1 & PC2 & PC3 & PC4 & color_intens \\
\hline color_ton & Pearson & 1 & $-.808^{* *}$ & $.740^{* *}$ & -.487 & -.290 & $-.606^{*}$ \\
PC1 & Pearson & $-.808^{* *}$ & 1 & $-.957^{* *}$ & .434 & .154 & .167 \\
PC2 & Pearson & $.740^{* *}$ & $-.957^{* *}$ & 1 & $-.592^{*}$ & -.017 & -.101 \\
PC3 & Pearson & -.487 & .434 & $-.592^{*}$ & 1 & -.502 & .219 \\
PC4 & Pearson & -.290 & .154 & -.017 & -.502 & 1 & .096 \\
color_intens & Pearson & $-.606^{*}$ & .167 & -.101 & .219 & .096 & 1 \\
& $\mathrm{~N}$ & 12 & 12 & 12 & 12 & 12 & 12 \\
\hline \hline
\end{tabular}

**Correlation is significant at the 0.01 level. *Correlation is significant at the 0.05 level

A correlation coefficient of -0.957 (close to maximum -1) between TASTE_dryastringent (PC1) and TASTE_sweetviscous (PC2) reflects a strong linear mapping of mainland Portugal PGIs, enabling a clear sensory profiling statement, virtually with a hierarchical reading, as shown in Figure 2e. Astringency was assessed as drier and rougher in the north and smoother in the South. Keeping in mind the sensory input based on the prototypical long-term memory of one of Portugal's finest panel of wine experts, this strong negative correlation is certainly showing a notion of balance and pleasure (Peynaud and Blouin, 1996). The astringent sensations of wine are considered pleasant when balanced with other factors, including alcohol and sugar content. If the grapes are picked early, a wine would have a tendency to have excess tannins and acidity, with a deficiency in polysaccharides, sugar and ethanol. As the fruit becomes more mature, the composition becomes more balanced and the descriptors become more positive (Kennedy, 2008). The lack of ethanol greatly increased the perceived acidity (GonzaloDiago et al., 2014). Such evidence relates strongly with PGIs where TASTE_dryastringent (PC1) is high and, conversely, where TASTE_sweetviscous (PC2) is low, and vice-versa. The bi-plot in Figure 2e showed a clear south to north decrease on grape ripeness and, consequently, in alcohol content. These findings may suggest that southern PGIs wines have 

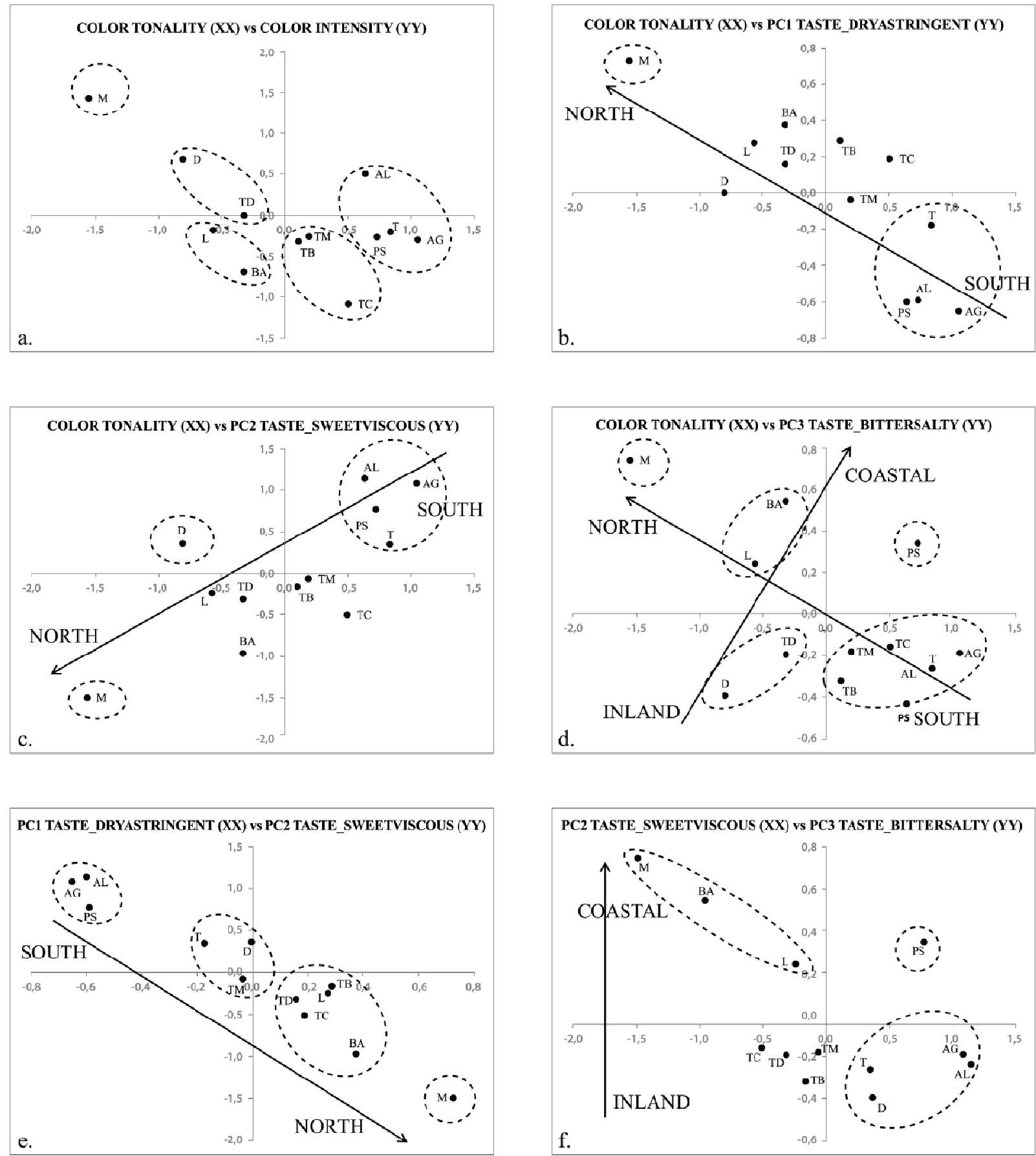

Figure 2. Standardized score bi-plots for six significant correlation of pair-wise sensory variables over 12 PGIs (PS - Península de Setúbal, T Tejo, AG - Algarve, AL - Alentejano, D - Duriense, TD - Terras do Dão, BA - Beira Atlântico, L - Lisboa, TB - Terras da Beira, TM Transmontano, TC - Terras de Cister, $\mathrm{M}$ - Minho)

Representações das variáveis sensoriais, em 6 planos bi-variados com correlações significativas, para as 12 PGIs (PS - Península de Setúbal, TTejo, AG - Algarve, AL - Alentejano, D - Duriense, TD - Terras do Dão, BA - Beira Atlântico, L - Lisboa, TB - Terras da Beira, TM Transmontano, TC - Terras de Cister, $M-$ Minho) 
higher polysaccharide contents. Moreover, the observation that the acidic polysaccharide rhamnogalacturonan (RG)-II significantly decreased the astringency of the model wine solution strongly suggests that the composition and structure of the polysaccharide fractions, not just their overall viscosity, influence their capacity to decrease astringency (Vidal et al., 2004a). Central inland valleys - encompassing PGI Duriense and PGI Terras do Dão - scored higher than neighboring continental PGIs, showing proximity towards the southern regions in terms of mild astringency perception. This could mean that wines with high levels of polysaccharides would present lower astringency, even if they had high polyphenolic content (Carvalho et al., 2006), which is the case in these two PGIs (Jordão and Correia, 2012; Sun et al., 2013); however, studies on geographical polysaccharide differentiation in Portuguese wines have yet to be presented.

Paired PC1 and PC2 showed clear confirmation that acids can elicit the sensation of astringency and a nationwide reading was clear as acidity increased from south to north. This result agrees with the previously reported observation that maximum intensity and total duration of astringency elicited by organic acids were decreased as the viscosity of the solution increased (Smith and Noble, 1998). Several studies agree with these findings, and others considered $\mathrm{pH}$ to be the key parameter influencing astringency level, rather than the acidic nature (Obreque-Slier et al., 2012) which was also finding will also confirmed in this study. A recent Portuguese study (Sun et al., 2013) confirmed that polymeric procyanidins show much higher reactivity toward salivary proteins than oligomeric ones. Moreover, the sensory panel analysis of these two procyanidin fractions further confirmed the higher astringency intensity of polymeric procyanidins $(\mathrm{mDP}=25)$ than the oligomeric ones $(\mathrm{mDP}=7.2)$. The results obtained by the late work showed that the astringency intensity of one-year-old red wines, introducing a (non-representative) geographical insight, was highly correlated with their polymeric proanthocyanidin content. Interestingly, no such correlation was found with total polyphenols or any individual phenolic compounds. These results indicate the important contribution of polymeric proanthocyanidins to red wine astringency, and that the levels of polymeric polyphenols in red wines may be used as an indicator for its astringency. According to the late assay, and correlating with the present outcome, an enriched oligomeric phenolic content in the southern region red wines should be expected.
Finally, the measure TASTE_bittersalty (PC3) included bitterness, saltiness and fizziness (natural or added CO2) perceptions on a nationwide level. The interpretation must be merely indicative, as the explained variance was weaker than PC1 and PC2 levels; however, those 3 aggregate scores/perceptions seemed to act as key profilers for a coastal/inland sensory differentiation, as shown in Figure 2d and $2 \mathrm{f}$. This finding even became statistically significant as a negative correlation of PC3 with TASTE_sweetviscous (PC2) showed a well-defined cluster including super humid coastal PGI Minho and temperate coastal PGI Beira Atlântico and PGI Lisboa, as well as a surprising stand-alone southern coastal region (PGI Península de Setúbal), which was replaced, in its customary cluster, by a sweet, lowest bitter-salty, north-continental PGI Duriense. The reason, perhaps, may have to do with the fact wine polysaccharides decrease the astringency and bitterness of procyanidins and elicit the sensation of fullness (Vidal et al., 2004b). Moreover, literature underlines the importance of $\mathrm{pH}$ and ethanol in modifying oligomeric tannin astringency and bitterness (Fontoin et al., 2008). Nevertheless, it is interesting to note that the nationwide differentiation of astringency and bitterness introduced an orthogonal reading ( $\mathrm{N}$ north- $\mathrm{S}$ south vs. E inland-W coastal), rather than a linear one. Physicochemical studies on wine composition have yet to address this line of investigation; however, recent climatic studies have already confirmed the late findings, to some extent (Tonietto et al., 2014).

\section{Outer key profilers, from reviewed physicochemical Portuguese studies}

Having put in perspective the errors that may occur from an in-depth interpretation of statistically insufficient published data, several nationwide tendencies and correlations may represent interesting findings and challenge unexplored avenues for new agricultural and wine chemistry research.

The blending of the previous six sensory variables, that have already been interpreted, with the means of 11 new variables emerging from the reviewed Portuguese studies on wine chemistry and climate was submitted to correlation analysis in order to narrow the interpretation space to a significant degree of linear association. This exercise was conducted with 8 major contributing wine regions due to the unavailability, to our knowledge, of published studies on wine phenolics focusing on PGI Transmontano, PGI Algarve, PGI Terras da Beira and PGI Terras de Cister (Table IV). 


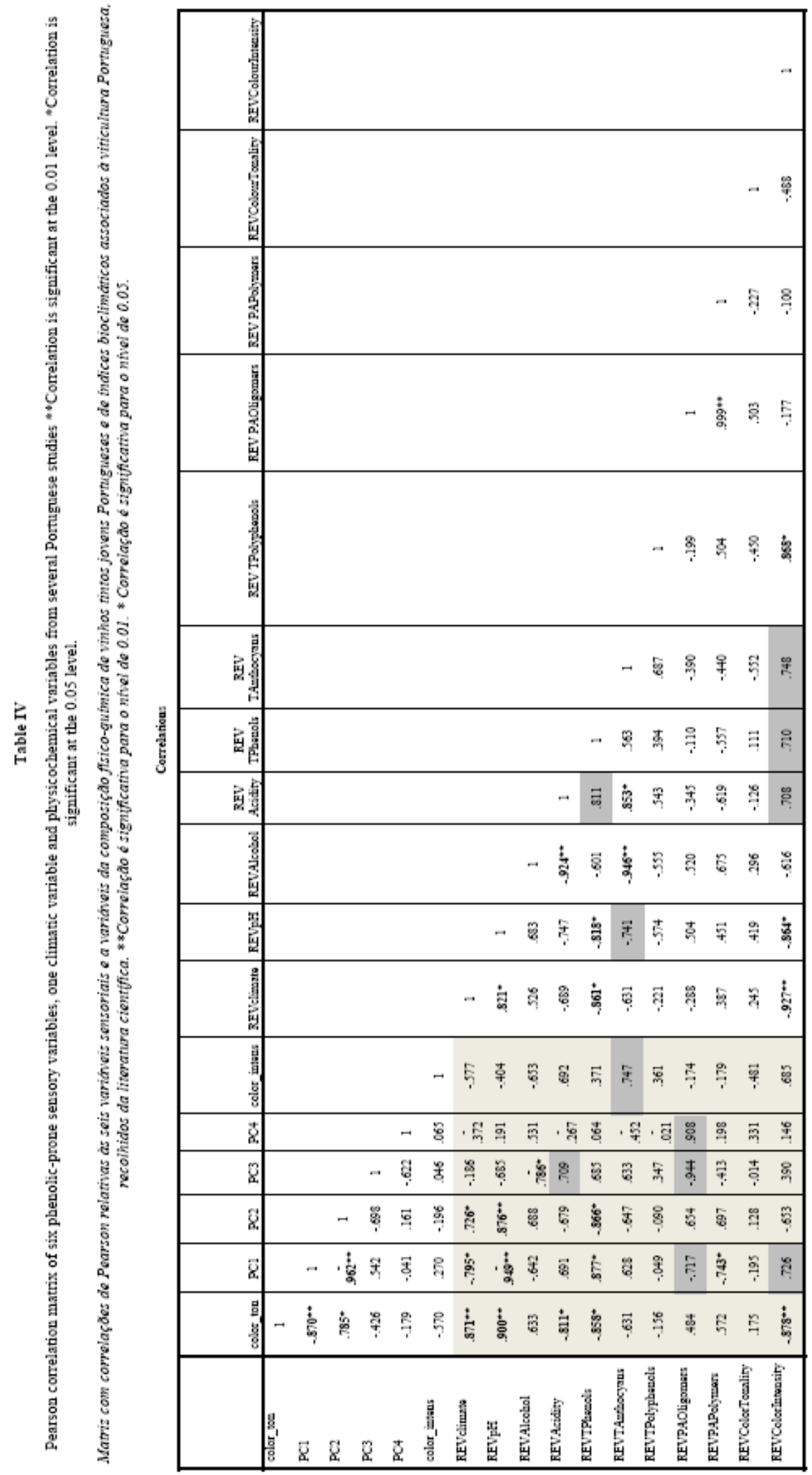


Lacking further and more focused Portuguese studies (Table II) to guarantee a robust statistical reading, the results from correlations between our novel sensory assay and physicochemical variables showed a promising strong/significant alignment in several measures. By combining bioclimatic aspects of heat accumulation, dryness, and ripening conditions, in a scale of 0 (unsuitably cold or excessively dry) to 16 (very warm, humid with warm nights), viticultural zoning related directly to PGI regions, as in the referenced literature previously addressed. Climate measure (REVClimate) along with $\mathrm{pH}$ and Total Phenol Index (A280) were significantly correlated and were the best physicochemical profilers in terms of Portuguese red wine typicality. The Total Phenol Index, determined by colorimetry, has been proposed
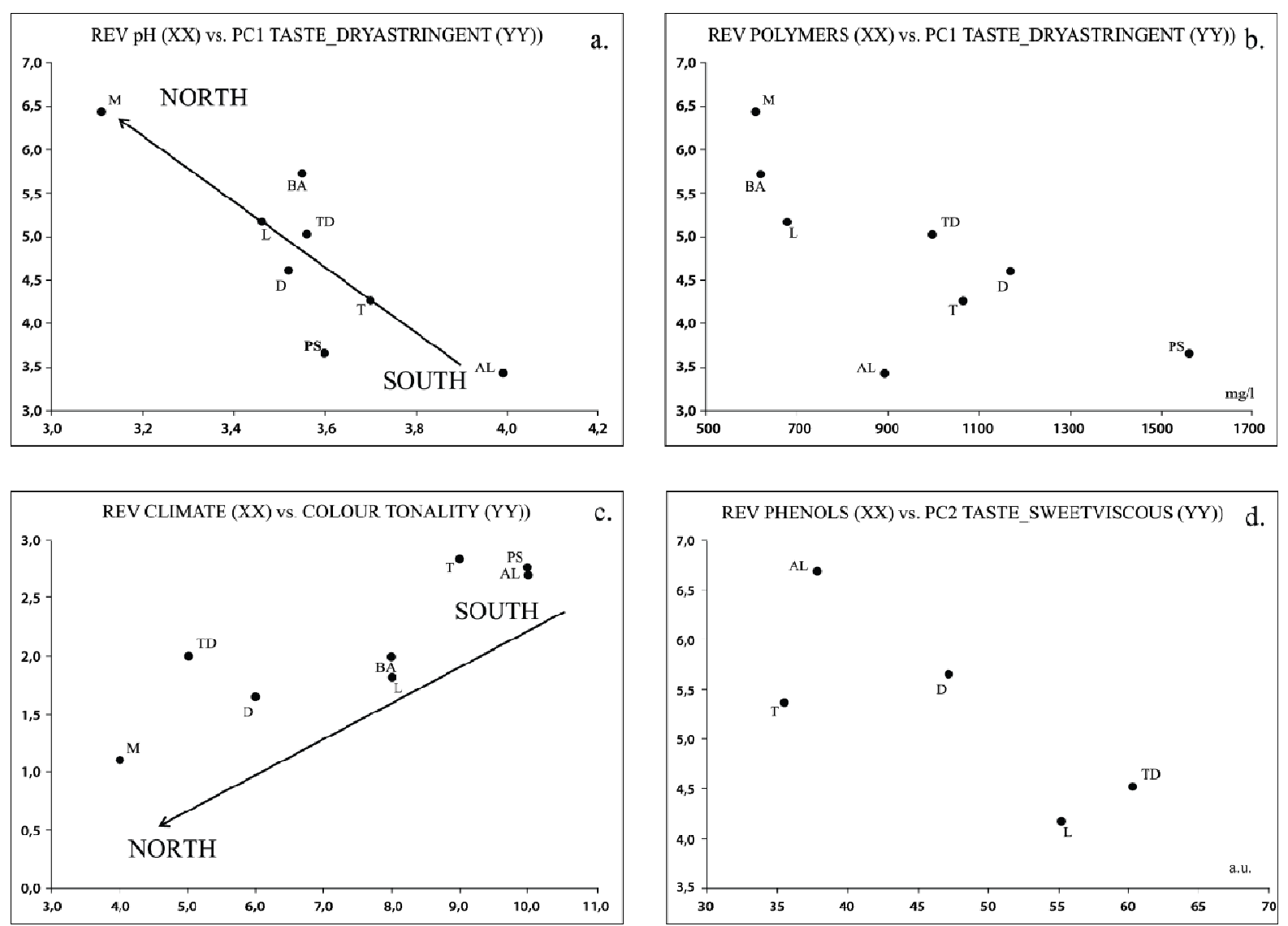

Figure 3. Non-standardized score bi-plots for six significant correlation of pair-wise sensory vs. reviewed variables over 12 PGIs (PS - Península de Setúbal, T - Tejo, AG - Algarve, AL - Alentejano, D - Duriense, TD - Terras do Dão, BA - Beira Atlântico, L - Lisboa, TB - Terras da Beira, TM - Transmontano, TC - Terras de Cister, $\mathrm{M}$ - Minho).

Representações de variáveis sensoriais vs. variáveis da literatura revista, em 4 planos bi-variados com correlações significativas, para as 12 PGIs (PS - Península de Setúbal, T - Tejo, AG - Algarve, AL - Alentejano, D - Duriense, TD - Terras do Dão, BA - Beira Atlântico, L - Lisboa, TB - Terras da Beira, TM - Transmontano, TC - Terras de Cister, M - Minho). as a quality marker (Bosch-Fusté et al., 2009); however the colorimetric phenol determination correlated poorly - although positively - with the total polyphenols analysis by spectrophotometric methods. The ratio of Phenolic Oligomeric/Polimeric red wine composition may be considered a good profiler (Sun et al., 2013), as well as total anthocyanins, even the colored-fraction alone, as Intensity showed significant negative correlation with sensory-scored Color Tonality and fairly high negative correlation with colorimetric ity (hue). This discussion may enrich a poorly explored area of nationwide zoning in terms of wine typicality but results and final bi-plots (Figure 3), as
promising as they might appear to be, should be accepted with a critical, almost challenging view. 


\section{CONCLUSIONS}

When an assay aims to evaluate the sensory or physicochemical characteristics of wines coming from a nationwide or even a PGI or PDO smaller extension, in order to profile its regional typicality, several methodological, statistical, logistical and time-consuming limitations are well-documented. Where classical wine-sampling methods proved to fail in terms of statistical significance, a classical scoring method based on long-term memory, and related prototypical constructs of undisputable Portuguese wine experts, which is sample-free, showed robust explained variance when a reduction of 18 aromatic and 14 gustatory descriptors to few principal components was applied and four macrozonings clustered the current 12 mainland Portugal wine regions; typical sensory differentiation was shown. In this assay, the four gustatory Principal Components, and the two initial color variables were cross-correlated along 12 mainland Portugal PGIs. Significant statistical factors confirmed Color Tonality, PC1 TASTE_dryastringent and PC2 TASTE_sweetviscous as strong profilers for wine zoning based on PGI's sensory typicality. Color tonality evolved from violet-blue in cooler northern

\section{REFERENCES}

Alcalde-Eon C., Escribano-Bailon M.T., Santos-Buelga C., RivasGonzalo, J.C., 2006. Changes in the detailed pigment composition of red wine during maturity and ageing - A comprehensive study. Anal. Chim. Acta, 563, 238-254.

Asenstorfer R.E., Lee D.F., Jones G.P., 2006. Influence of structure on the ionisation constants of anthocyanin and anthocyanin-like wine pigments. Anal. Chim. Acta, 563, 10-14.

Birse M.J., 2007. The Colour of Red Wine. 306 p. PhD Thesis, University of Adelaide.

Bosch-Fusté J., Sartini E., Flores-Rubio C., Caixach J., LópezTamames E., Buxaderas S., 2009. Viability of total phenol index value as quality marker of sparkling wines, "cavas.” Food Chem., 114, 782-790

Boulton R., 2001. The Copigmentation of Anthocyanins and Its Role in the Color of Red Wine: A Critical Review. Am. J. Enol. Vitic., 2, 67-87.

Brouillard R., 1988. Flavonoids and flower colour. In: J. B. Harborne (ed.), The Flavonoids 16, 525-538, Springer US.

Cabrita M.J., Aires-de-Sousa J., Gomes da Silva M.D.R., Rei F., Costa Freitas A.M., 2012. Multivariate statistical approaches for wine classification based on low molecular weight phenolic compounds. Aust. J. Grape Wine Res., 18, 138-146.

Cabrita M.J., Ricardo-da-Silva J.M., Laureano O., 2003. Polyphenolic Compounds of Grapes and Wines. In: 1st International Seminar of Viticulture and Wine Making, 61-102, Ensenada, Mexico.

Cadot Y., Caille S., Samson A., Barbeau G., Cheynier V., 2010. Sensory dimension of wine typicality related to a terroir by regions to ruby-garnet down on hotter southern Mediterranean regions. Encompassed in the PC2 aggregate measure, acidity was enhanced from south to north. Conversely, alcohol and viscosity increased southward. Sensory differences were found between bitterness and astringency, and bitterness was more influenced by the inland-coastal effect. The nationwide differentiation of astringency and bitterness introduced an orthogonal reading ( $\mathrm{N}$ north$S$ south vs. E inland-W coastal, respectively), rather than a linear one, these findings adding novelty to sensory research.

Several studies on the physicochemical composition of young Portuguese red wines and on the bioclimatic influence on viticulture were reviewed and the findings - although scarce and statistically non-significant - were correlated with the previous six sensory measures. Bioclimatic indexes, $\mathrm{pH}$ and colorimetric Total Phenol Index were considered to be stronger profilers in a nationwide assessment on red wine typicality. The ratio of phenolic oligomeric/polimeric composition and total anthocyanins - even the colored fraction alone - were also considered to be potential sensory profilers.

Quantitative Descriptive Analysis, Just About Right analysis and typicality assessment. Anal. Chim. Acta, 660, 53-62.

Carvalho E., Mateus N., Plet B., Pianet I., Dufourc E., De Freitas V., 2006. Influence of wine pectic polysaccharides on the interactions between condensed tannins and salivary proteins. $J$. Agric. Food Chem., 54, 8936-8944.

Castillo-Sánchez J.X., García-Falcón M.S., Garrido J., MartínezCarballo E., Martins-Dias L. R., Mejuto X.C., 2008. Phenolic compounds and colour stability of Vinhão wines: Influence of wine-making protocol and fining agents. Food Chem., 106, 18-26.

Charlton A.J., Baxter N.J., Khan M.L., Moir A.J.G., Haslam E., Davies A.P., Williamson M.P., 2002. Polyphenol/peptide binding and precipitation. J. Agric. Food Chem., 50, 1593-1601.

Cheynier V., Comte G., Davies K.M., Lattanzio V., Martens S. 2013. Plant phenolics: Recent advances on their biosynthesis, genetics, andecophysiology. Plant Physiol. Biochem., 72, 1-20.

Cosme F., Ricardo-Da-Silva J.M., Laureano O., 2009. Tannin profiles of Vitis vinifera L. cv. red grapes growing in Lisbon and from their monovarietal wines. Food Chem., 112, 197-204.

Costa E., Cosme F., Jordão A.M., Mendes-Faia A., 2014. Anthocyanin profile and antioxidant activity from 24 grape varieties cultivated in two Portuguese wine regions. J. Int. La Sci. La Vigne Du Vin, 48, 51-62.

Costa M.G., Cabrita M.J., Rosario C., Laureano O., 1998. Contribution for physicochemical characterization of 3 Alentejo cultivars. In: 4th Viticultural Symposium of Alentejo, 97-104, Évora.

Cristea E., 2014. Determination of the optimal Phenolic Extration in red wines using the Glories method. 61 p. Master Thesis, Universidade Católica Portuguesa. 
Cristino R., Costa E., Cosme F., Jordão A.M., 2013. General phenolic characterisation, individual anthocyanin and antioxidant capacity of matured red wines from two Portuguese Appellations of Origins. J. Sci. Food Agric., 93, 2486-2493.

Dallas C., Laureano O., 1994. Effect of SO2 on the extraction of individual anthocyanins and colored matter of three Portuguese grape varieties during winemaking. Vitis, 33, 41-47.

Dopico-García M.S., Fique A., Guerra L., Afonso J.M., Pereira O., Valentão P., Seabra R.M.,. 2008. Principal components of phenolics to characterize red Vinho Verde grapes: anthocyanins or non-coloured compounds? Talanta, 75, 1190-202.

Esparza I., Santamaría C., Calvo I., Fernández, J.M., 2009. Significance of CIELAB parameters in the routine analysis of red wines. CyTA - J. Food, 7, 189-199.

Fernandes P., Ricardo-da-Silva J.R., Castro R., 2010. Comportamento Agronómico e Enológico das Castas Syrah e Touriga Nacional em seis “Terroirs" de Portugal. In: $8^{\circ}$ Simpósio de Vitivinicultura do Alentejo, 143-153. Évora.

Fernández-Pachón M.S., Villaño D., García-Parrilla M.C., Troncoso A.M., 2004. Antioxidant activity of wines and relation with their polyphenolic composition. Anal. Chim. Acta, 513, 113118.

Fischer U., Christmann M., Heeß U., Hoffmann U., Eisenbarth J., Tesch H., 1999. Development of an Aroma Wheel for German White and Red Wines. In 24th OIV World Vine and Wine Congress 2, 201-207. Mainz.

Fontoin H., Saucier C., Teissedre P.-L., Glories Y., 2008. Effect of $\mathrm{pH}$, ethanol and acidity on astringency and bitterness of grape seed tannin oligomers in model wine solution. Food Qual. Prefer., 19, 286-291.

Fraga H., Malheiro A.C., Moutinho-Pereira J., Jones G.V., Alves F., Pinto J.G., Santos J.A., 2013. Very high resolution bioclimatic zoning of Portuguese wine regions: present and future scenarios. Reg. Environ. Chang., 14, 295-306.

Fraga H., Santos J.A., Malheiro A.C., Moutinho-Pereira J., 2012. Climate Change Projections for the Portuguese Viticulture using a Multi-Model Ensemble. Ciência Tec. Vitiv., 27, 39-48.

García-Puente E.R., Alcalde-Eon C., Santos-Buelga C., RivasGonzalo J.C., Escribano-Bailón M.T., 2006. Behaviour and characterisation of the colour during red wine making and maturation. Anal. Chim. Acta, 563, 215-222.

Gawel R., 1998. Red wine astringency: a review. Aust. J. Grape Wine Res., 4, 74-95.

Gawel R., Iland P.G., Francis I.L., 2001. Characterizing the astringency of red wine: a case study. Food Qual. Prefer., 12, 8394.

Gawel R., Oberholster A., Francis I.L., 2000. A "Mouth-feel Wheel": terminology for communicating the mouth-feel characteristics of red wine. Aust. J. Grape Wine Res., 6, 203-207.

Gonçalves F.J., Jordão A.M., 2009. Influence of different commercial fining agents on proanthocyanidin fraction and antioxidant activity of a red wine from baga grapes. J. Int. Des Sci. La Vigne Du Vin, 43, 111-120.

Gonçalves F.J., Rocha S.M., Coimbra M.A., 2012. Study of the retention capacity of anthocyanins by wine polymeric material. Food Chem., 134, 957-963.

González-Manzano S., Mateus N., De Freitas V., Santos-Buelga C., 2008. Influence of the degree of polymerisation in the ability of catechins to act as anthocyanin copigments. Eur. Food Res. Technol., 227, 83-92.
Gonzalo-Diago A., Dizy M., Fernández-Zurbano P., 2014. Contribution of low molecular weight phenols to bitter taste and mouthfeel properties in red wines. Food Chem., 154, 187-198.

Harrar V., Spence C., 2013. The taste of cutlery: how the taste of food is affected by the weight, size, shape, and colour of the cutlery used to eat it. Flavour, 2, 21.

Hernández B., Sáenz C., de la Hoz J.F., Alberdi C., Alfonso S., Diñeiro J.M., 2009. Assessing the color of red wine like a taster's eye. Color Res. Appl., 34, 153-162.

Jordão A.M., Correia A.C., 2012. Relationship between antioxidant capacity, proanthocyanidin and anthocyanin content during grape maturation of Touriga Nacional and Tinta Roriz grape varieties. South African J. Enol. Vitic., 33, 214-224.

Jordão A.M., Gonçalves F.J., Correia A.C., Cantão A.J., RiveroPérez M.D., SanJosé M.L.G., 2010. Proanthocyanidin content, antioxidant capacity and scavenger activity of portuguese sparkling wines (Bairrada Appellation of Origin). J. Sci. Food Agric., 90, 2144-2152.

Jordão A.M., Simoes S., Correia A.C., Goncalves F.J., 2012. Antioxidant activity evolution during portuguese red wine vinification and their relation with the proanthocyanidin and anthocyanin composition. J. Food Process. Preserv., 36, 298-309.

Jose-Coutinho A., Avila P., Ricardo-Da-Silva J.M., 2013. Contribuição para a caracterização sensorial dos vinhos tranquilos tintos com Indicação Geográfica Protegida de Portugal Continental. Enologia, 61, 25-34.

Jose-Coutinho A., Avila P., Ricardo-Da-Silva J.M., 2015. Sensory Profile of Portuguese White Wines Using Long-Term Memory: A Novel Nationwide Approach. J. Sens. Stud., 30, 381-394.

Kennedy J.A., 2008. Grape and wine phenolics: Observations and recent findings. Cienc. Y Investig. Agrar., 35, 107-120.

Lesschaeve I., Noble A.C., 2005. Polyphenols: factors influencing their sensory properties and their effects on food and beverage preferences. Am. J. Clin. Nutr., 81, 330S-335S.

Magalhães N., Oliveira A., Caeiro L., 1995. Contributo para a caracterização climática das Regiões Vitícolas de Portugal Continental. In: $3^{\circ}$ Simpósio de Vitivinicultura do Alentejo 1, 8190. Évora.

Maitre I., Symoneaux R., Jourjon F., Mehinagic E., 2010. Sensory typicality of wines: How scientists have recently dealt with this subject. Food Qual. Prefer., 21, 726-731.

Marquez A., Serratosa M.P., Merida J., 2013. Pyranoanthocyanin derived pigments in wine: Structure and formation during winemaking. J. Chem., 2013, 1-15.

Mateus N., Machado J.M., de Freitas V., 2002. Development changes of anthocyanins in Vitis vinifera grapes grown in the Douro Valley and concentration in respective wines. J. Sci. Food Agric., 82, 1689-1695.

McRae J.M., Kennedy J.A., 2011. Wine and grape tannin interactions with salivary proteins and their impact on astringency: A review of current research. Molecules, 16, 2348-2364.

Monagas M., Bartolomé B., Gómez-Cordovés C., 2005. Updated knowledge about the presence of phenolic compounds in wine. Crit. Rev. Food Sci. Nutr., 45, 85-118.

Noble A.C., Arnold R.A., Buechsenstein J., Leach E.J., Schmidt J.O., Stern P.M.. 1987. Modification of a standardized system of wine aroma terminology. Am. J. Enol. Vitic., 38, 143-146.

Obreque-Slier E., Peña-Neira Á., López-Solís R., 2012. Interactions of enological tannins with the protein fraction of saliva 
and astringency perception are affected by pH. LWT - Food Sci. Technol., 45, 88-93.

Parr W.V, Heatherbell D., White K.G., 2002. Demystifying wine expertise: olfactory threshold, perceptual skill and semantic memory in expert and novice wine judges. Chem. Senses, 27, 74755.

Peynaud E., Blouin J., 1996. The Taste of Wine: The Art Science of Wine Appreciation. 346 p. John Wiley \& Sons, Ltd.

Quijada-Morín N., Williams P., Rivas-Gonzalo J.C., Doco T., Escribano-Bailón M.T., 2014. Polyphenolic, polysaccharide and oligosaccharide composition of Tempranillo red wines and their relationship with the perceived astringency. Food Chem., 154, 4451.

Rodrigues A., Ricardo-Da-Silva J.M., Lucas C., Laureano O., 2013. Effect of winery yeast lees on touriga nacional red wine color and tannin evolution. Am. J. Enol. Vitic., 64, 98-109.

Scollary G.R., Pásti G., Kállay M., Blackman J., Clark A.C., 2012. Astringency response of red wines: Potential role of molecular assembly. Trends Food Sci. Technol., 27, 25-36.

Smith A.K., Noble A.C., 1998. Effects of increased viscosity on the sourness and astringency of aluminum sulfate and citric acid. Food Qual. Prefer., 9, 139-144.

Spielmann N., 2012. Terroir? That's not how I would describe it. Int. J. Wine Bus. Res., 24, 254-270.

Suarez R., Monagas M., Bartolome B., Gomez-Cordoves C., 2007. Phenolic composition and colour of Vitis vinifera L. CV merlot wines from different vintages and aging time in bottle. Ciência Téc. Vitiv., 22, 35-44.

Sun B., Neves A.C., Fernandes T.A., Fernandes A.L., Mateus N., De Freitas V., Spranger M.I., 2011. Evolution of phenolic composition of red wine during vinification and storage and its contribution to wine sensory properties and antioxidant activity. $J$. Agric. Food Chem., 59, 6550-6557.
Sun B., Ricardo-Da-Silva J.M., Spranger M.I., 2001. Quantification of catechins and proanthocyanidins in several Portuguese grapevine varieties and red wines. Ciência Téc. Vitiv., 16, 23-34.

Sun B., Sa M., Leandro C., Caldeira I., Duarte F., Spranger M.I., 2013. Reactivity of Polymeric Proanthocyanidins toward Salivary Proteins. J. Agric. Food Chem., 61, 939-946.

Tonietto J., Ruiz V.S., Zanus M.C., Montes C., 2014. The effect of viticultural climate on red and white wine typicity. Characterization in Ibero-American grape-growing regions. J. Int. La Sci. La Vigne Du Vin, (Special Laccave), 19-23.

Tuorila H., Monteleone E., 2009. Sensory food science in the changing society: Opportunities, needs, and challenges. Trends Food Sci. Technol., 20, 54-62.

Valentova H., Skrovankova S., Panovska Z., Pokorny J., 2002. Time-intensity studies of astringent taste. Food Chem., 78, 29-37.

Vaudour E., Shaw A.B., 2005. A worldwide perspective on viticultural zoning. South African J. Enol. Vitic., 26, 106-115.

Vidal S., Francis L., Noble A., Kwiatkowski M., Cheynier V., Waters E., 2004a. Taste and mouth-feel properties of different types of tannin-like polyphenolic compounds and anthocyanins in wine. Anal. Chim. Acta, 513, 57-65.

Vidal S., Francis L., Williams P., Kwiatkowski M., Gawel R., Cheynier V., Waters E., 2004b. The mouth-feel properties of polysaccharides and anthocyanins in a wine like medium. Food Chem., 85, 519-525.

Vilanova M., Genisheva Z., Masa A., Oliveira J.M., 2010. Correlation between volatile composition and sensory properties in Spanish Albarino wines. Microchem. J., 95, 240-246.

Vivar-Quintana A.M., Santos-Buelga C., Rivas-Gonzalo J.C. 2002. Anthocyanin-derived pigments and colour of red wines. Anal. Chim. Acta, 458, 147-155. 